\title{
25 Research Square \\ Anionic Surfactants Monitoring In Healthcare Facilities - A Case of Belo Horizonte City, Brazil
}

Graziela Torres Trajano

Ezequiel Dias Foundation: Fundacao Ezequiel Dias

Olívia Maria S Ribeiro Vasconcelos

Ezequiel Dias Foundation: Fundacao Ezequiel Dias

Luiz Carlos Moutinho Pataca

Ezequiel Dias Foundation: Fundacao Ezequiel Dias

Marcos Paulo Gomes Mol ( $\nabla$ marcos.mol@funed.mg.gov.br)

Ezequiel Dias Foundation: Fundacao Ezequiel Dias https://orcid.org/0000-0002-2568-3579

\section{Research Article}

Keywords: Hospital effluents, surfactants, hospitals, LAS, QAC

Posted Date: August 13th, 2021

DOI: https://doi.org/10.21203/rs.3.rs-697490/v1

License: (c) (i) This work is licensed under a Creative Commons Attribution 4.0 International License. Read Full License

Version of Record: A version of this preprint was published at Environmental Monitoring and Assessment on March 5th, 2022. See the published version at https://doi.org/10.1007/s10661-022-09877-x. 


\section{Abstract}

Surfactants are substances that when in aquatic environments, can cause negative impacts. Hospital effluents carry numerous chemicals daily, including surfactants, used in sanitization and disinfection procedures. These chemicals are found in different concentrations in the effluents and reach water bodies due to a lack of proper removal in the wastewater treatment plants. The present study investigated data about effluents monitoring from healthcare facilities located in the city of Belo Horizonte, Brazil, focusing on anionic surfactants. The results showed, in 2018, a total of 72 establishments monitoring this parameter, resulting in a median concentration of $1 \mathrm{mg} \cdot \mathrm{L}^{-1}$ of anionic surfactants in the period. Cationic surfactants still do not have specific legislation in the studied country that dictates a limit for discharge into sewage, however, these compounds are used in the formulation of routine hospital products.

\section{Introduction}

Daily, hospital effluents convey several chemical substances, often without previous treatment. When they reach the wastewater treatment plants, the removal of many chemicals is not always sufficient, thus, several substances can reach aquatic environments and cause damage to the ecosystem, and human health. Given this context, correctly identifying the most critical substances is a strategy to promote more efficient monitoring of liquid effluents generated by healthcare facilities, thinking about strategies for more effective removals, which contribute to the mitigation of the harmful effects on aquatic environments (Al Aukidy et al. 2014; Niemi et al. 2020; Verlicchi et al. 2010).

Surfactants substances are commonly present in hospital effluents. These substances are known for having a polar and an non-polar part, characteristics that make them able to have an affinity with both oil and water, and form micelles in solution (Bergé et al. 2018; Daltin 2011; Palmer and Hatley 2018; Tadros 2013). Because of their properties, these substances are used in the manufacture of soaps and detergents, products frequently used in hospital activities as sanitizing agents due to their solubilizing capacity and detergent action, conferred by the formation micelles (Daltin 2011; Tadros 2013). Among other classifications, surfactants can be mainly of three types: anionic, cationic, or non-ionic, established by the electric charge on the hydrophilic part of its molecule (Daltin 2011). As noted by (Palmer and Hatley 2(018), the wastewater treatment plants do not yet focus on removing surfactants. Depending on the classification, the action of detergents may vary, for instance, by provoking the solubilization of proteins or modifying the structures and activities of enzymes (Panouillères et al. 2007), which can make their treatment process and removal difficult. Some examples of surfactants used in hospitals around the world are shown in Table 1. 
Table 1

Surfactants commonly used in hospital environments around the world

\begin{tabular}{|c|c|c|c|}
\hline Surfactant & Group/Family & Hospital Application & Reference \\
\hline $\begin{array}{l}\text { Didecyl dimethyl ammonium } \\
\text { chloride (DDAC) }\end{array}$ & $\begin{array}{l}\text { Cationic Surfactant/ } \\
\text { Quaternary Ammonium } \\
\text { Compounds (QACs) }\end{array}$ & $\begin{array}{l}\text { Antiseptic for skin } \\
\text { Surface maintenance } \\
\text { Disinfectant detergent for medical } \\
\text { instruments, clothing, and } \\
\text { operating room fabrics }\end{array}$ & $\begin{array}{l}\text { (Lasek et al. } \\
\text { 2019) } \\
\text { (Zhang et al. } \\
2015) \text {. }\end{array}$ \\
\hline $\begin{array}{l}\text { Chlorhexidine digluconate } \\
\text { (CHD) }\end{array}$ & $\begin{array}{l}\text { Cationic Surfactant / } \\
\text { QACs }\end{array}$ & $\begin{array}{l}\text { Biocide } \\
\text { Antiseptic for skin, and hand } \\
\text { preparation for surgery and } \\
\text { obstetrics } \\
\text { Disinfectant for surgical } \\
\text { instruments }\end{array}$ & $\begin{array}{l}\text { (Lasek et al. } \\
\text { 2019) } \\
\text { (Karpiński and } \\
\text { Szkaradkiewicz } \\
\text { 2015) }\end{array}$ \\
\hline $\begin{array}{l}\text { Bis(aminopropyl)laurylamine } \\
\text { (BAPLA) }\end{array}$ & $\begin{array}{l}\text { Anionic } \\
\text { Surfactant/tertiary } \\
\text { amine }\end{array}$ & $\begin{array}{l}\text { Surface maintenance and } \\
\text { cleaning of food area and } \\
\text { equipment; } \\
\text { Antimicrobial: destroys or inhibits } \\
\text { the growth of bacteria, } \\
\text { minimizing the spread of disease } \\
\text { Can be used to impregnate into } \\
\text { fabrics } \\
\text { Disinfectant detergent for } \\
\text { surfaces }\end{array}$ & $\begin{array}{l}\text { (Lasek et al. } \\
2019)\end{array}$ \\
\hline
\end{tabular}

In particular, the quaternary ammonium compounds (QACs) are a family of molecules that belong to the group of cationic surfactants, widely used as active products in the manufacture of disinfectants and softeners, due to their high affinity to negatively charged surfaces (Hora et al. 2020) and antimicrobial action, mainly against gram-negative bacteria and lipid membranes of enveloped viruses (Lasek et al. 2019; Pereira and Tagkopoulos 2019). Therefore, they are very useful in hospital disinfection activities. Their basic structure can be represented by $\left(\mathrm{R}_{4} \mathrm{~N}^{+}\right) \mathrm{X}^{-}$, and by changing the R groups, several other compounds were developed, expanding their effectiveness and applicability through the inactivation of energy-producing enzymes, denaturation of proteins, and cell membrane breakdown. In the presence of organic matter, soaps and anionic surfactants can inactivate QACs (Brasil 2005; Gerba 2015).

The products containing QACs are a mix of compounds with alkyl chain sizes ranging from C8 to C18, whereby compounds with C12 and C14 exhibit higher biocidal activity (Pereira and Tagkopoulos 2019). In 2016 the European Union established regulations on the use of biocides derived from QACs, restringing its use in personal care products such as hand and body antiseptics (EU 2016).

Anionic compounds are widely used in the formulation of household and industrial detergents (Penteado et al. 2006). According to Steber (2007), they are the most used in cleaning products. Linear alkylbenzene sulfonate (LAS) is one of the families in this group. Like the QACs, LAS also composes the formulation of laundry products (Roberts 2003). Penteado et al. (2006) showed that the presence of these substances in the environment can be harmful to aquatic life and highlighted problems in water bodies such as the decrease in dissolved oxygen, among others. 
The Brazilian Federal Standard, Resolution CONAMA n³57 of 2005 (Brasil 2005), establishes the standards for the effluents discharged into water bodies. Among the physicochemical parameters, the surfactants monitored, either for fresh, saline, and brackish waters, comprise only those that react with methylene blue, a colorimetric analytical technique that allows the determination of anionic surfactants (Brasil 2005). CONAMA 357 does not include limits for other surfactant groups, such as cationic surfactants, which means that they are not monitored.

Sampling for the determination of cationic surfactants presents problems related to their strong ability to adsorb. Therefore, to keep the compounds of interest available to be determined, a mixture of LAS in chloroform is added immediately after sampling. The chloroform helps to prevent adsorption onto the glass walls, while the LAS forms stable complexes with the quaternary ammonium compounds, transferring them to the organic phase (MartínezCarballo et al. 2007).

Even though surfactants of the cationic group are not monitored, they can be found in the compositions of detergents and disinfectants used in healthcare establishments in Brazil (Santa Bárbara et al. 2012). Several authors have mentioned the use of QUACs, and their growth in the disinfectant market over the years, around the world (Kümmerer et al. 1997; Hora et al. 2020; Zion Market Research 2021), which may imply the increase in the concentration of these compounds in hospital effluents.

With the SARS-CoV-2 (COVID-19) crisis there has been a significant increase in the use of disinfectants, and these are used in homes, commercial areas, industry, and public transportation systems (Hora et al. 2020). In healthcare centers, these have always been used throughout the hospital routine due to the range of different types of cleaning and disinfection, procedures, equipment, surfaces, and clothing. Through the continuous use in hospital activities, these organic compounds reach the effluents, being able to react with other substances.

Given the concern of the presence of surfactants in the environment, this study investigated data about the monitoring of liquid effluents from healthcare facilities located in the city of Belo Horizonte, Brazil, focusing on anionic surfactants. It is further emphasized that some groups of surfactants are not monitored due to the current legislation from Brazil.

\section{Methodology}

The monitoring data analyzed cover the period from September 2007 to January 2019. The initial database provided contained 395586 results related to physicochemical parameters, monitored in 78 healthcare facilities such as hospitals, clinics, and outpatient clinics. Monitoring of the effluent from each establishment was quarterly and covered years vary for each establishment. All establishments are located in the city of Belo Horizonte, capital of the State of Minas Gerais, Brazil. The data analyzed in this study were provided by the municipal sanitation company, which, to authorize the receiving of non-domestic effluents, such as healthcare establishments, requires the discharge of the effluent following the conditions and limits of physicochemical parameters and biological characteristics (COPASA 2018). All physicochemical and biological parameters were analyzed related to surfactant presence, using statistical tools.

Initially, the data was pre-processed to be organized and to eliminate inconsistencies and insignificant data. The database was rearranged, and since some parameters were monitored several times a day, such as temperature and $\mathrm{pH}$, the median for these parameters was calculated in the rearrangement. Then the parameters whose amount of data was scarce were discarded. Some parameters had very extreme values that indicated the presence of outliers. These extreme values were removed by using the boxplot where the upper limit of the whisker was calculated to be 
twenty times the interquartile range. A total of 390 values were considered the outliers, which corresponded to $0.5 \%$ of the spreadsheet values. After pre-processing, the data matrix showed a total of 28 parameters (Total Aluminum, Benzene, Total Boron, Total Cyanides, Total Copper, Hexavalent Chromium, Total Chromium, BOD, COD, Ethylbenzene, Total Phenols, Total Iron, Total Fluoride, Oils and Grease, Total Mercury, Total Nickel, Ammoniacal Nitrogen, $\mathrm{pH}$, Total Silver, Suspended Solids, Sedimentable Solids, Surfactants, Sulfates, Total Sulfide, Temperature, Toluene, Xylenes, Total Zinc) and 2902 lines (days sampled).

After pre-processing, the facilities were divided into three groups. The first group of establishments was allocated as Large and University Hospitals. In the second group are the Medium-sized Hospitals, Maternity and Orthopedic Hospitals, and in the third group were allocated the other establishments (Small Hospitals - outpatient clinic and health insurance, Day Hospital, Eye Surgery, Rehabilitation Clinics, Clinics, Blood Centers, Hemodialysis, Reproductive Medicine, Nephrology, Ophthalmology, Oncology, Otorhinolaryngology, Emergency Room, Radiology, Urology, and Psychiatric Hospital).

A multiple linear regression model was created with the parameter Surfactant Substances as the dependent variable and the other 27 parameters as independent variables. All data analyses, including preprocessing, were performed using the R Language and Environment for Scientific Computing (R Core Team 2020).

\section{Results And Discussions}

\subsection{Parameters identified in the monitored hospital effluents}

Table 2 presents the descriptive statistics for the Surfactants parameter, being analyzed the substances that react with methylene blue, LAS (ABNT NBR 10738:1989, SMWW 5540:2017, ASTM D4251-89:2016, ISO 7875-1:1996/COR 1:2003) (ABNT 1989; ISO 2003; D12 Committee 2016; Baird and Bridgewater 2018), monitored in the analyzed hospitals. Since the data do not follow a normal distribution, the median is the best estimator of the central position of the data, and the absolute deviation from the median (MAD) as the data dispersion estimator. The number of establishments that presented effluent measurements was increasing over the years. In 2007 only one establishment was monitoring it in the effluents. In 2018, a total of 72 establishments were performing the same monitoring. For the year 2019, there are data only for January, which explains why there are only 31 establishments for the year. 
Table 2

Descriptive statistics of surfactant measurements $\left(\mathrm{mg} \cdot \mathrm{L}^{-1}\right)$ over the years

\begin{tabular}{|llllllllll|}
\hline Years & Health care facilities & Samples & Mean & SD & Median & MAD & Min & Max & IQR \\
\hline 2007 & 1 & 2 & 1.50 & 0.83 & 1.50 & 0.87 & 0.918 & 2.09 & 0.58 \\
\hline 2008 & 6 & 18 & 1.63 & 0.93 & 1.54 & 0.93 & 0.24 & 3.26 & 1.16 \\
\hline 2009 & 20 & 118 & 3.05 & 9.4 & 1.38 & 0.97 & 0.08 & 80.21 & 1.28 \\
\hline 2010 & 29 & 140 & 2.02 & 2.6 & 1.28 & 1.2 & 0.0 & 17.80 & 1.79 \\
\hline 2011 & 50 & 258 & 7.42 & 65 & 1.14 & 0.93 & 0.0 & 829.38 & 1.50 \\
\hline 2012 & 54 & 292 & 2.04 & 2.1 & 1.50 & 1.5 & 0.0 & 18.10 & 2.31 \\
\hline 2013 & 54 & 301 & 2.07 & 3.6 & 1.18 & 1.4 & 0.0 & 45.40 & 2.11 \\
\hline 2014 & 56 & 307 & 1.99 & 3.7 & 1.10 & 1.1 & 0.0 & 44.00 & 2.05 \\
\hline 2015 & 63 & 335 & 1.68 & 2.8 & 0.997 & 1.1 & 0.0 & 31.00 & 1.51 \\
\hline 2016 & 66 & 342 & 1.81 & 2.7 & 0.938 & 1.2 & 0.0002 & 22.40 & 1.97 \\
\hline 2017 & 71 & 380 & 2.71 & 6.0 & 0.738 & 0.94 & 0.0 & 49.20 & 1.81 \\
\hline 2018 & 72 & 378 & 1.52 & 2.7 & 0.500 & 0.59 & 0.0 & 22.75 & 1.36 \\
\hline 2019 & 31 & 31 & 1.05 & 1.4 & 0.680 & 0.76 & 0.0 & 6.96 & 0.96 \\
\hline All & 78 & 2852 & 2.49 & 19.8 & 1.00 & 1.1 & 0 & 829.38 & 1.84 \\
\hline Legend: SD: standard deviation; MAD: median absolute deviation; Min: minimum value; Max: maximum value; \\
\hline IQR: interquartile range.
\end{tabular}

As observed in Table 2, the median value for the monitored hospitals between 2007 and 2019 was $1 \mathrm{mg} . \mathrm{L}^{-1}$ while the mean value was $2.49 \mathrm{mg} . \mathrm{L}^{-1}$. In a research hospital in Istanbul, Turkey, with 780 beds, anionic surfactants were also identified in the raw hospital effluent (Top et al. 2020), ranging from 0.26 to $2.08 \mathrm{mg} \cdot \mathrm{L}^{-1}$ and with a mean value of $1.96 \mathrm{mg} \cdot \mathrm{L}^{-1}$. This shows that the values found during the monitored period in hospitals in Belo Horizonte have similarities in some years, being below those presented by this author. Studies of hospital effluents in France showed lower values, and cationic and non-ionic surfactants were also analyzed. In the study conducted by the SIPIBEL project, France, near the Swiss border, anionic surfactants were analyzed in the dissolved fraction of samples collected from hospital and municipal effluents for two years. The data obtained showed the highest presence of anionic surfactants in urban effluents, with values similar to those found in Brazilian hospital effluents: $2 \mathrm{mg} \cdot \mathrm{L}^{-1}$; and in hospital effluents, the median obtained was $0.40 \mathrm{~m} \cdot \mathrm{L}^{-1}$. In hospital effluents, cationic and non-ionic surfactants predominated (Wiest et al. 2018), which are not yet required by Brazilian legislation.

Selecting variables to be used in the multiple linear regression model, twenty regression models were initially created using random sampling of $50 \%$ of the data. For each model, separated sampling was done. Of the 27 independent variables used in the models, only the variables Chromium VI, Chromium, COD, Phenols, and Sulfides were significant in all models created in this step and were selected as variables for the final regression model. The final regression model was created using $67 \%$ of the randomly sampled data. The remaining $33 \%$ were used for model validation. Table 3 summarizes the coefficients of the final regression model. 
Table 3

Coefficients of the final regression model

\begin{tabular}{|lllll|}
\hline & Estimate & Std. Dev. & Error & p value* \\
\hline (Intercept) & 0.790 & 0.12 & 6.8 & $1.08 \times 10^{-11}$ \\
\hline Chrome VI & 10,1 & 1.4 & 7.4 & $1.47 \times 10^{-13}$ \\
\hline Chromium & -6.16 & 1.4 & -4.4 & $1.33 \times 10^{-5}$ \\
\hline COD & 0.00251 & 0.00022 & 12 & $<2.00 \times 10^{-16}$ \\
\hline Phenols & -0.635 & 0.22 & -2.9 & 0.00399 \\
\hline Sulfide & 0.991 & 0.13 & 7.5 & $7.18 \times 10^{-14}$ \\
\hline Legend: Std. Dve.: standard deviation; *: significative values when $\mathrm{p}<0.05$ \\
\hline
\end{tabular}

The regression model had an adjusted $\mathrm{R}^{2}$ of 0.1446 . The standard error of the model residuals was 2.879 , which corresponds to a coefficient of variation of 1.48 . For the validation data, the $\mathrm{R}^{2}$ was 0.1418 , and the standard error of the residuals was 2.786 , which are similar values to the values obtained for the regression model, which showed the validity of the model.

In the final regression model, positive correlations were found for the variables Chromium VI, COD, and Sulfides, as presented in Table 2, suggesting a high value of these parameters associated with high value of surfactants. Considering negative correlations, Chromium and Phenols, the lower these parameters, the higher the value of the surfactants. The presence of surfactants in effluents could lead to an increase in COD values, and the positive correlation presented in Table 2 confirmed this hypothesis. In presence of surfactants the phenol could be solubilized in the micelles, and cations ( $\mathrm{M} 2+$ and $\mathrm{M} 3+)$ promoted the capture of these micelles, corroborating the negative correlation. These cations are present in the hospital wastewaters (Sultana, et al., 2021; Cavalcante et al, 2018). Sulphites can be formed in the degradation of bacteria.

\subsection{Surfactants concentrations identified in the literature}

The effluents generated in hospital laundries present different characteristics from the others, due to the high volume of water and great complexity, such as the presence of different classes of surfactants and detergents, besides the high microbial and viral load, pharmaceuticals and common parameters in all effluents (Kern et al. 2015; Zotesso et al. 2017; Lutterbeck et al. 2020). Table 4 presented the surfactant concentrations of studies conducted in countries such as France, Switzerland, and Turkey. In the survey conducted by Lutterbeck et al. (2020), treatment processes and toxicity of influents and effluents from the laundry of a 180-bed hospital, which generates $150 \mathrm{~m}^{3}$ of effluent daily, were evaluated. Of this volume, $33 \%$ is produced in the hospital laundry. The mass balance of the laundry products used in each step of the process was performed, obtaining the following values for consumption of $6.3 \mathrm{~m}^{3}$ of water: nonylphenol ethoxylate: $43.7 \mu \mathrm{g} \cdot \mathrm{L}^{-1}$; sodium hydroxide: $220 \mu \mathrm{g} / \mathrm{L}$; hydrogen peroxide: $190 \mu \mathrm{g} / \mathrm{L}$; quaternary de ammonium compounds: $63.5 \mu \mathrm{g} \cdot \mathrm{L}^{-1}$; and sodium bisulfite: $31 \mu \mathrm{g} \cdot \mathrm{L}^{-1}$. The acute ecotoxicity tests, with $D$. magna, revealed, for the raw effluent, extreme toxicity (EC50 24.5\%). After undergoing effluent treatments, a $100 \%$ EC50 was obtained, indicating non-toxicity (Lutterbeck et al. 2020). In 2015, Kern and collaborators also analyzed the laundry effluent from the same hospital and identified the following surfactants: lauryl ethoxylate, benzoic acid, n-(4aminophenyl)-n-methylacetamide, 2-(diethylamino)-n-(2,6-dimethylphenyl)-acetamide), and methyl-m-(1-methylbutyl) phenyl ester, by gas chromatography. 
In the study of Lasek et al. (2019), effluents from a French university hospital, whose water consumption corresponds to $482 \mathrm{~L} /$ bed, were analyzed through the collection of samples carried out in campaigns between the years 2016 and 2017. The authors observed the concentrations of three substances that have detergent-disinfectant actions, the CHD, DDAC, and BAPLA, in 3 isolated collection points, as well as at the point of confluence between all effluents. The concentrations in $\mathrm{mg} \cdot \mathrm{L}^{-1}$ observed for the sampling campaigns are expressed in Table 4 . In the research by Kovalova et al. (2012) the authors analyzed the effluent from a Swiss hospital to evaluate the removal of micropollutants and disinfectants. 
Table 4

Concentrations of surfactants detected in hospital effluents

\begin{tabular}{|c|c|c|c|}
\hline Surfactants & Place sampled & $\begin{array}{l}\text { Concentration } \\
\left(\mathrm{mg} \cdot \mathrm{L}^{-1}\right)\end{array}$ & Source \\
\hline \multirow[t]{2}{*}{ DDAC } & $\begin{array}{l}\text { Oncology, Laundry, cardiology, geriatrics, } \\
\text { pulmonology, main pharmacy }\end{array}$ & $1.52-3.25$ & \multirow[t]{6}{*}{$\begin{array}{l}\text { (Lasek et } \\
\text { al. 2019) }\end{array}$} \\
\hline & $\begin{array}{l}\text { The main building of the hospital: } \\
\text { medical clinic, operating rooms, } \\
\text { endoscopy, and intensive care units }\end{array}$ & $0.93-2.33$ & \\
\hline \multirow[t]{2}{*}{$\mathrm{CHD}$} & $\begin{array}{l}\text { Oncology, Laundry, cardiology, geriatrics, } \\
\text { pulmonology, main pharmacy }\end{array}$ & $0.027-0.056$ & \\
\hline & $\begin{array}{l}\text { The main building of the hospital: } \\
\text { medical clinic, operating rooms, } \\
\text { endoscopy, and intensive care units }\end{array}$ & $0.031-0.097$ & \\
\hline \multirow[t]{2}{*}{ BAPLA } & $\begin{array}{l}\text { Oncology, Laundry, cardiology, geriatrics, } \\
\text { pulmonology, the main pharmacy }\end{array}$ & $0.031-0.097$ & \\
\hline & $\begin{array}{l}\text { The main building of the hospital: } \\
\text { medical clinic, operating rooms, } \\
\text { endoscopy, and intensive care units }\end{array}$ & $0.018-0.093$ & \\
\hline Anionic & \multirow{3}{*}{$\begin{array}{l}\text { Median concentrations for the sampling } \\
\text { campaigns conducted from } 2013 \text { to } \\
2015\end{array}$} & 0.4 & \multirow{3}{*}{$\begin{array}{l}\text { (Wiest et } \\
\text { al. 2018) }\end{array}$} \\
\hline Cationic & & 1.1 & \\
\hline Nonionic & & 4.9 & \\
\hline \multirow[t]{2}{*}{ Anionic } & Raw hospital wastewater & $4.55 \times 10^{-4}$ & \multirow{6}{*}{$\begin{array}{l}\text { (Buelow } \\
\text { et al. } \\
2020)\end{array}$} \\
\hline & Treated hospital effluent & $3.57 \times 10-5$ & \\
\hline \multirow[t]{2}{*}{ Cationic } & Raw hospital wastewater & $5.51 \times 10-4$ & \\
\hline & Treated hospital effluent & $1.28 \times 10-4$ & \\
\hline \multirow[t]{2}{*}{ Nonionic } & Raw hospital wastewater & $6.27 \times 10-3$ & \\
\hline & Treated hospital effluent & $3.155 \times 10-5$ & \\
\hline Anionic & \multirow[t]{4}{*}{ Average sample in $24 \mathrm{~h}$} & $<0.01$ & \multirow{4}{*}{$\begin{array}{l}\text { (Boillot et } \\
\text { al. 2008) }\end{array}$} \\
\hline Cationic & & 5.0 & \\
\hline Glutaraldehyde & & 0.0021 & \\
\hline Nonionic & & 2.9 & \\
\hline \multirow{2}{*}{$\begin{array}{l}\text { Anionic, upstream and downstream } \\
\text { of hospital effluent discharge from } \\
\text { February to May } 2011\end{array}$} & Arve River & $<0.10$ & \multirow{6}{*}{$\begin{array}{l}\text { (Perrodin } \\
\text { et al. } \\
2013 \text { ) }\end{array}$} \\
\hline & Hospital Effluent & $<0.05$ & \\
\hline \multirow{4}{*}{$\begin{array}{l}\text { Cationic, upstream and downstream } \\
\text { of hospital effluent discharge from } \\
\text { February to May } 2011\end{array}$} & Arve River & $<0.4$ & \\
\hline & Hospital Effluent & & \\
\hline & Arve River & $<0.4$ e 1 & \\
\hline & Hospital Effluent & & \\
\hline
\end{tabular}




\begin{tabular}{|c|c|c|c|}
\hline Surfactants & Place sampled & $\begin{array}{l}\text { Concentration } \\
\left(\mathrm{mg} \cdot \mathrm{L}^{-1}\right)\end{array}$ & Source \\
\hline \multirow{5}{*}{$\begin{array}{l}\text { Nonionic, upstream and downstream } \\
\text { of hospital effluent discharge from } \\
\text { February to May } 2011\end{array}$} & & \multirow[t]{3}{*}{$<2$} & \\
\hline & Arve River & & \\
\hline & Hospital Effluent & & \\
\hline & Arve River & \multirow[t]{2}{*}{16.8 e 17.9} & \\
\hline & Hospital Effluent & & \\
\hline \multirow[t]{2}{*}{ Nonionic } & Raw Hospital Effluent & 4.24 a 19.95 & \multirow{6}{*}{$\begin{array}{l}\text { (Perrodin } \\
\text { et al. } \\
2016 \text { ) }\end{array}$} \\
\hline & Effluent after HWW & $<0.01$ & \\
\hline \multirow[t]{2}{*}{ Anionic } & Raw Hospital Effluent & $<0.05$ a 0.24 & \\
\hline & Effluent after HWW & $<0.05$ & \\
\hline \multirow[t]{2}{*}{ Cationic } & Raw Hospital Effluent & $<0.4$ & \\
\hline & Effluent after HWW & $<0.4$ & \\
\hline QAC BAC C12-18 & - & 0.049 & \multirow{3}{*}{$\begin{array}{l}\text { (Kovalova } \\
\text { et al. } \\
\text { 2012) }\end{array}$} \\
\hline BAC $\mathrm{C} 12$ & - & 0.034 & \\
\hline DDAC-C10 & - & 0.102 & \\
\hline Anionic & Average & 1.96 & $\begin{array}{l}\text { (Top et al. } \\
2020 \text { ) }\end{array}$ \\
\hline
\end{tabular}

Through the statistical analyses developed, correlations were observed between the surfactants and other physicochemical parameters found in the monitored effluents of small, medium-sized, and large healthcare establishments (Table 5), in which the highest correlations observed originated in the effluents from the large establishments. The correlation of surfactants with oils was observed in all healthcare establishment sizes, except for medium-sized. The oils may originate from the effluents from the kitchen of the healthcare establishment's facilities. The correlation of surfactants with this parameter may be linked to their solubility in lipids, characterized by the hydrophobic part present in the structure of these organic compounds (Nakama 2017).

Table 5

Correlations observed between anionic surfactants with other parameters monitored in small to medium-sized healthcare establishments effluents

\begin{tabular}{|c|c|c|c|c|c|c|c|c|c|}
\hline Grouping/parameter & Aluminum & Ammonium & Boron & BOD & COD & Phenols & Nickel & Sulfide & Oils \\
\hline All & - & - & - & & - & - & - & - & $\star * *$ \\
\hline Large & $\star \star$ & $\star \star \star \star$ & * & - & 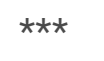 & $\star \star \star \star$ & $\star \star \star \star$ & 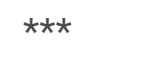 & 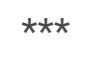 \\
\hline Medium & - & - & - & - & - & - & - & - & - \\
\hline Small & - & - & - & $\star \star$ & $\star *$ & - & - & - & 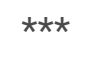 \\
\hline
\end{tabular}


The current Brazilian legislation that dictates the conditions and standards for effluent discharge includes only the limits for anionic surfactants. The "Deliberação Normativa Conjunta" COPAM/CERH-MG nº 01, of May 5th, 2008 (Minas Gerais 2008), legislation in force in the State of Minas Gerais, Brazil, establishes the conditions and standards for effluent discharge into surface waters. For the organic parameters, which include surfactants that react with methylene blue, the limit set for discharge, except for public treatment systems, is $2.0 \mathrm{mg} \cdot \mathrm{L}^{-1}$ of LAS, (Minas Gerais 2008). Regarding the quality standards for surface water, both in the state and federal legislation, CONAMA $357 / 2005$, the maximum value to be maintained is $0.5 \mathrm{mg} \cdot \mathrm{L}^{-1}$ of LAS. The "Companhia de Saneamento do Estado de Minas Gerais - COPASA", defines the limits for the discharge of non-domestic effluents into the public collecting system, through Technical Standard T.187/6, in which the expected concentration allowed for surfactant substances is $5 \mathrm{mg} \cdot \mathrm{L}^{-1}$ (COPASA 2018).

Cationic and nonionic surfactants do not yet have specific legislation for effluent discharge into sewage, consequently into surface waters (Brasil 2005; de Sousa et al. 2012; Jesus et al. 2013; Lasek et al. 2019). They have been detected in influent and effluent as well as in sludge samples from wastewater treatment plants. The WWTPs partially remove the QACs, and thus these compounds reach the environment. The action of microorganisms presents in the water body and natural photodegradation is slow, leading to an increase of these compounds in both waters and sediments (Pati and Arnold 2020). The attenuation mechanisms of these compounds in aquatic environments are slow photolysis and biodegradation, in addition to sorption on suspended materials, which can sediment (EPA 2006), causing persistence. They are also found adsorbed on sludge from aerobic and anaerobic processes. A total of $167 \mathrm{mg} \cdot \mathrm{kg}^{-1}$ of total QACs was found in sewage sludge in Guangzhou, China (Li et al. 2014). The sludge from 52 WWTPs scattered across China was analyzed, seeking to identify the presence of adsorbed QACs. In the analyses of alkyl trimethyl ammonium, benzyl alkyl dimethyl ethyl ammonium, and dialkyl dimethyl ammonium homologues by LC MS/MS, the concentration range data found were $0.38-294 \mu \mathrm{g} \cdot \mathrm{g}^{-1}, 0.94-191 \mu \mathrm{g} \cdot \mathrm{g}^{-1}$, and 0.64-343 $\mu \mathrm{g} \cdot \mathrm{g}^{-1}$, respectively (Ruan et al. 2014). Chlorhexidine digluconate (CHD) showed toxicity in aquatic organisms, the lowest toxicity being to algae Pseudokirchneriella subcapitata (41.3 $\mu \mathrm{g} \cdot \mathrm{L}^{-1}$, EC50, $\left.24 \mathrm{~h}\right)$ and to Vibrio fischeri $3675.2 \mu \mathrm{g} \cdot \mathrm{L}^{-1}$, EC50 after 5 min assay (Jesus et al. 2013).

\subsection{Available analytical methodologies to identify and quantify different surfactants}

The analytical methodologies for the determination of surfactants in environmental samples have grown over the years in the world, but their implementation in the control of their release into the environment is still slow. This can be attributed to the process and the investments in equipment and standards for certification. The great diversity of compounds and metabolites can contribute to the complexity of this problem.

For environmental samples, anionic surfactants have well-established methods, such as the spectrophotometric method, which determines the active substances that react with methylene blue, the compounds derived from LAS, which was used to determine surfactants in the samples of this study. For the determination of nonionic surfactants in environmental samples, the cobalt thiocyanate reacting substances method (SMWW 5540:2018), and the method using Dragendorff reagent (ISO 7875-2:1984) (ISO 1984) have been used. Regarding cationic surfactants, instrumental analytical methodologies have been used, such as HPLC, LC MS, LC MS/MS, with higher costs involved in the acquisition of equipment and supplies. Moreover, analytical standards are required in addition to the metabolites formed, which are not always available for purchase. It also involves the pre-treatment of liquid and solid samples, from the collection and preservation until the solid phase extraction, its recovery, and the validation of the methodology (Paijens et al. 2020). 


\subsection{Physicochemical characteristic of healthcare establishments effluents and their contribution to the discharge of surfactants in the sewage system and related impacts}

The effluents from the laundry of the Regional University Hospital of Maringá, in the state of Paraná (Brazil) showed $130 \mathrm{mg} \cdot \mathrm{L}^{-1}$ and $240 \mathrm{mg} \cdot \mathrm{L}^{-1}$ of BOD and COD, respectively. Products are used in the different stages of the process, being basically cationic surfactants (Furtado et al. 2020). In that study, the effects of cytotoxicity were investigated with Allium cepa L., with the effluents from each step of the process, and after treatment by a physicochemical process, and this one, associated with $\mathrm{UV} / \mathrm{H}_{2} \mathrm{O}_{2}$ processes. That effluent showed to be cytotoxic by inhibiting the cell division of Allium cepa L. (Furtado et al. 2020). When investigating the efficiency of hospital effluent treatment using UV photocatalysis and ozonation, Souza et al. (2018) were able to remove surfactants from the effluent generated by an 840-bed hospital in Porto Alegre, Brazil. The initial concentration of anionic surfactants was at $4.96 \mathrm{mg} \cdot \mathrm{L}^{-1}$, reduced to $4.25 \mathrm{mg} \cdot \mathrm{L}^{-1}$ after the coagulation process, and after the application of $\mathrm{O}_{3} / \mathrm{UV}$ treatment, they found 0.218 $\mathrm{mg} \cdot \mathrm{L}^{-1}$ and a reduction of total organic carbon by $54.7 \%$ (Souza et al. 2018).

Surfactants and their degradation products have been found in several concentrations in effluents, treated sludge, surface water, solids, sediments, among others, offering risks to the environment (Ying 2006; Olkowska et al. 2014). In Brazil, detergents can still contain phosphorus in their composition, a nutrient that contributes to the eutrophication phenomenon. Von Sperling (2014), explains that up to $50 \%$ of the phosphorus found in domestic sewage may originate from detergents (Von Sperling 2014). According to Panouillères and collaborators (2007), detergents and disinfectants are among the main substances that cause toxicity to aquatic species. The toxic effects to the biotic community have been discussed in the literature and differ according to the organism and the concentration to which it is exposed.

Wang et al. (2015) studied the effects caused by anionic, cationic, and nonionic surfactants on embryos and larval stage of zebrafish. The authors identified results as delayed embryo development and changes in larval locomotion activities. Lechuga et al. (2016) reported the toxicity of surfactants on Daphnia magna, luminescent bacteria, Vibrio fischeri, and freshwater and saltwater microalgae. The results show that Vibrio fischeri exhibited the highest sensitivity to the surfactants tested, although the other organisms were also affected to a lesser extent. Boillot and Perrodin (2008) showed the combination of glutaraldehyde with surfactants (anionic, cationic, and nonionic), both used in hospital routines, and their toxic effects related to the mobility of Daphnia Magna. Other authors have studied the toxic effects of surfactants and combinations with these compounds, to Daphnia Magna (Emmanuel et al. 2005; Hodges et al. 2006; Lechuga et al. 2016). Nałęcz-Jawecki et al. (2003) analyzed the toxicity of QACs on Vibrio fischeri, ciliated protozoa, and Artemia franciscana. The authors concluded that these compounds showed toxicity to all organisms tested.

Finally, as presented by Lutterbeck and colleagues (2020a), hospital laundry wastewater can pose negative impacts to human and environmental health, and this topic is rarely discussed in the scientific literature, when discussing the treatment of these effluents. Also, treatment alternatives did not show a complete solution to the toxic effects of this effluent. In this context, concepts as cleaner production and zero waste are important to reduce the quantity of surfactants in the wastewater and, consequently, reducing the toxicity of effluents generated by healthcare facilities. Changing the process with the same hygiene security procedure represents an opportunity in this context.

\section{Conclusions}


Hospital effluents have a different composition than domestic effluents. The use of the municipal sewer system to release hospital effluents can result in interactions between compounds present in the two types of effluents, which can lead to undesired reactions, such as the bioavailability of the compounds modifying the final toxicity. This study showed an increase in healthcare establishments number monitoring anionic surfactants in their effluents. Although anionic surfactants are the most used in cleaning products formulations, cationic surfactants are also found in daily hospital routine products. In Brazil, the current legislation for effluent discharge standards does not mention this group of surfactants, which may have biocidal properties.

Due to the number of compounds used in the hospital routines, monitoring must be sufficient to ensure that hazardous substances do not reach and harm the environment. Therefore, the importance of monitoring surfactants in hospital effluents is highlighted, since the presence of these compounds and their degradation products, carried daily in their effluents, eventually reach water bodies, and may impact organisms and the environment. The management of daily products to guarantee the zero waste of surfactants and maintain the hygiene quality is an important perspective to consider in hospital decisions.

\section{Declarations}

\section{Ethical Approval}

Not applicable

\section{Consent to Participate}

Not applicable

\section{Consent to Publish}

Not applicable

\section{Authors Contributions}

Conception and design: OMSRV and MPGM. Data analysis: GTT, OMSRV, LCMP, and MPGM. Manuscript drafting: GTT, OMSRV, and LCMP. Manuscript revision: MPGM. Final version approval of the manuscript: All authors.

\section{Funding}

The authors disclosed receipt of the following financial support for the research, authorship, and/or publication of this article: Financial support provided by Fundação de Amparo à Pesquisa do Estado de Minas Gerais (FAPEMIG) and Conselho Nacional de Desenvolvimento Científico e Tecnológico (CNPq)

\section{Availability of Data and Materials}

The datasets generated and/or analyzed during the current study are not publicly available (specific information about healthcare establishments) but are available from the corresponding author on reasonable request.

\section{Competing Interests}

The authors declare that they have no competing interests.

\section{Acknowledgements}


The authors thank COPASA for providing the data and information to carry out this study.

\section{References}

1. ABNT AB de NT (1989) ABNT NBR 10738:1989 - Água - Determinação de surfactantes aniônicos pelo método espectrofotométrico do azul-de-metileno - Método de ensaio. ABNT - Associação Brasileira de Normas Técnicas, Rio de Janeiro

2. APHA (2012) Standard Methods for the Examination of Water and Wastewater, 22 edn. American Public Health Association, Washington

3. Al Aukidy M, Verlicchi P, Voulvoulis N (2014) A framework for the assessment of the environmental risk posed by pharmaceuticals originating from hospital effluents. Sci Total Environ 493:54-64.

https://doi.org/10.1016/j.scitotenv.2014.05.128

4. Baird R, Bridgewater L (2018) 5540 SURFACTANTS. In: Standard Methods For the Examination of Water and Wastewater, 23rd edn. American Public Health Association, Washington, D.C

5. Bergé A, Wiest L, Baudot R et al (2018) Occurrence of multi-class surfactants in urban wastewater: contribution of a healthcare facility to the pollution transported into the sewerage system. Environ Sci Pollut Res 25:92199229. https://doi.org/10.1007/s11356-017-0470-8

6. Boillot C, Bazin C, Tissot-Guerraz F et al (2008) Daily physicochemical, microbiological and ecotoxicological fluctuations of a hospital effluent according to technical and care activities. Sci Total Environ 403:113-129. https://doi.org/10.1016/j.scitotenv.2008.04.037

7. Boillot C, Perrodin Y (2008) Joint-action ecotoxicity of binary mixtures of glutaraldehyde and surfactants used in hospitals: Use of the Toxicity Index model and isoblogram representation. Ecotoxicol Environ Saf 71:252-259. https://doi.org/10.1016/j.ecoenv.2007.08.010

8. Brasil CN do MA (2005) Resolução CONAMA n 357, de 17 de março de 2005.Dispõe sobre a classificação dos corpos de água e diretrizes ambientais para o seu enquadramento, bem como estabelece as condições e padrões de lançamento de efluentes, e dá outras providências. Diário Of. União 58-63

9. Buelow E, Rico A, Gaschet M et al (2020) Hospital discharges in urban sanitation systems: Long-term monitoring of wastewater resistome and microbiota in relationship to their eco-exposome. Water Res X 7:100045. https://doi.org/10.1016/j.wroa.2020.100045

10. Cavalcante PRM, Melo RPF, Castro Dantas TN et al (2018) Removal of phenol from aqueous medium using micellar solubilization followed by ionic flocculation. J Environ Chem Eng 6:2778-2784.

https://doi.org/10.1016/j.jece.2018.04.025

11. COPASA C de S de MG (2018) Norma Técnica - T.187/6. Lançamento. de Efluentes Não Domésticos no Sistema de Esgotamento Sanitário da COPASA

12. D12 Committee (2016) ASTM D4251-89(2016) - Test Method for Active Matter in Anionic Surfactants by Potentiometric Titration. ASTM International, West Conshohocken

13. Daltin D (2011) Tensoativos: química, propriedades e aplicações, 1st edn. Blucher, São Paulo

14. de Sousa FC, Santana HT, de Miranda MM et al (2012) Segurança do paciente em serviços de saúde: limpeza e desinfecção de superfícies. Agência Nacional de Vigilância Sanitária, Brasília

15. Emmanuel E, Hanna K, Bazin C et al (2005) Fate of glutaraldehyde in hospital wastewater and combined effects of glutaraldehyde and surfactants on aquatic organisms. Environ Int 31:399-406.

https://doi.org/10.1016/j.envint.2004.08.011

Page 14/17 
16. EPA EPA (2006) EPA739-R-06-009 - Reregistration Eligibility Decision for Alkyl Dimethyl Benzyl Ammonium Chloride (ADBAC). Environmental Protection Agency, Washington, D.C

17. EU EU (2016) Commission Implementing Decision (EU) 2016/1950 of 4 November 2016 on the non-approval of certain biocidal active substances pursuant to Regulation (EU) No 528/2012 of the European Parliament and of the Council (Text with EEA relevance)

18. Furtado AO, Almeida IV, Almeida ACC et al (2020) Evaluation of hospital laundry effluents treated by advanced oxidation processes and their cytotoxic effects on Allium cepa L. Environ Monit Assess 192:360. https://doi.org/10.1007/s10661-020-08328-9

19. Gerba CP (2015) Quaternary Ammonium Biocides: Efficacy in Application. Appl Environ Microbiol 81:464-469. https://doi.org/10.1128/AEM.02633-14

20. Hodges G, Roberts DW, Marshall SJ, Dearden JC (2006) The aquatic toxicity of anionic surfactants to Daphnia magna-A comparative QSAR study of linear alkylbenzene sulphonates and ester sulphonates. Chemosphere 63:1443-1450. https://doi.org/10.1016/j.chemosphere.2005.10.001

21. Hora PI, Pati SG, McNamara PJ, Arnold WA (2020) Increased Use of Quaternary Ammonium Compounds during the SARS-CoV-2 Pandemic and Beyond: Consideration of Environmental Implications. Environ Sci Technol Lett 7:622-631. https://doi.org/10.1021/acs.estlett.0c00437

22. ISO IO for S (2003) ISO 7875-1:1996/Cor 1:2003 - Water quality - Determination of surfactants - Part 1: Determination of anionic surfactants by measurement of the methylene blue index (MBAS) - Technical Corrigendum 1. International Organization for Standardization, Geneva

23. ISO IO for S (1984) ISO 7875-2:1984 - Water quality - Determination of surfactants - Part 2: Determination of non-ionic surfactants using Dragendorff reagent. International Organization for Standardization, Geneva

24. Jesus FT, Oliveira R, Silva A et al (2013) Lethal and sub lethal effects of the biocide chlorhexidine on aquatic organisms. Ecotoxicology 22:1348-1358. https://doi.org/10.1007/s10646-013-1121-6

25. Karpiński TM, Szkaradkiewicz AK (2015) Chlorhexidine-pharmaco-biological activity and application. Eur Rev Med Pharmacol Sci 19:1321-1326

26. Kern DI, de Oliveira Schwaickhardt R, Lutterbeck CA et al (2015) Ecotoxicological and Genotoxic Assessment of Hospital Laundry Wastewaters. Arch Environ Contam Toxicol 68:64-73. https://doi.org/10.1007/s00244-0140072-0

27. Kovalova L, Siegrist H, Singer H et al (2012) Hospital Wastewater Treatment by Membrane Bioreactor: Performance and Efficiency for Organic Micropollutant Elimination. Environ Sci Technol 46:1536-1545. https://doi.org/10.1021/es203495d

28. Kümmerer K, Eitel A, Braun U et al (1997) Analysis of benzalkonium chloride in the effluent from European hospitals by solid-phase extraction and high-performance liquid chromatography with post-column ion-pairing and fluorescence detection. J Chromatogr A 774:281-286. https://doi.org/10.1016/S0021-9673(97)00242-2

29. Lasek F, Karpel Vel Leitner N, Rauwel G et al (2019) Discharge of biocidal products from healthcare activities into a sewage system-a case study at a French university hospital. Environ Sci Pollut Res 26:4938-4951. https://doi.org/10.1007/s11356-018-3882-1

30. Lechuga M, Fernández-Serrano M, Jurado E et al (2016) Acute toxicity of anionic and non-ionic surfactants to aquatic organisms. Ecotoxicol Environ Saf 125:1-8. https://doi.org/10.1016/j.ecoenv.2015.11.027

31. Li X, Luo X, Mai B et al (2014) Occurrence of quaternary ammonium compounds (QACs) and their application as a tracer for sewage derived pollution in urban estuarine sediments. Environ Pollut 185:127-133. https://doi.org/10.1016/j.envpol.2013.10.028

Page 15/17 
32. Lutterbeck CA, Machado ÊL, Sanchez-Barrios A et al (2020) Toxicity evaluation of hospital laundry wastewaters treated by microbial fuel cells and constructed wetlands. Sci Total Environ 729:138816.

https://doi.org/10.1016/j.scitotenv.2020.138816

33. Lutterbeck CA, Colares GS, Dell'Osbel N et al (2020a) Hospital laundry wastewaters: A review on treatment alternatives, life cycle assessment and prognosis scenarios. J Clean Prod 273:122851.

https://doi.org/10.1016/j.jclepro.2020.122851

34. Martínez-Carballo E, Sitka A, González-Barreiro C et al (2007) Determination of selected quaternary ammonium compounds by liquid chromatography with mass spectrometry. Part I. Application to surface, waste and indirect discharge water samples in Austria. Environ Pollut 145:489-496. https://doi.org/10.1016/j.envpol.2006.04.033

35. Minas Gerais CE de PA (2008) Deliberação Normativa Conjunta COPAM/CERH-MG nº 01, de 05 de maio de 2008 - Dispõe sobre a classificação dos corpos de água e diretrizes ambientais para o seu enquadramento, bem como estabelece as condições e padrões de lançamento de efluentes, e dá outras providências. J. Minas Gerais

36. Nakama Y (2017) Chap. 15 - Surfactants. In: Sakamoto K, Lochhead RY, Maibach HI, Yamashita Y (eds) Cosmetic Science and Technology. Elsevier, Amsterdam, pp 231-244

37. Nałęcz-Jawecki G, Grabińska-Sota E, Narkiewicz P (2003) The toxicity of cationic surfactants in four bioassays. Ecotoxicol Environ Saf 54:87-91. https://doi.org/10.1016/S0147-6513(02)00025-8

38. Niemi L, Taggart M, Boyd K et al (2020) Assessing hospital impact on pharmaceutical levels in a rural 'source-tosink' water system. Sci Total Environ 737:139618. https://doi.org/10.1016/j.scitotenv.2020.139618

39. Olkowska E, Ruman M, Polkowska Ż (2014) Occurrence of Surface Active Agents in the Environment. J Anal Methods Chem 2014:e769708. https://doi.org/10.1155/2014/769708

40. Paijens C, Frère B, Caupos E et al (2020) Determination of 18 Biocides in Both the Dissolved and Particulate Fractions of Urban and Surface Waters by HPLC-MS/MS. Water Air Soil Pollut 231:210. https://doi.org/10.1007/s11270-020-04546-6

41. Palmer M, Hatley H (2018) The role of surfactants in wastewater treatment: Impact, removal and future techniques: A critical review. Water Res 147:60-72. https://doi.org/10.1016/j.watres.2018.09.039

42. Panouillères M, Boillot C, Perrodin Y (2007) Study of the combined effects of a peracetic acid-based disinfectant and surfactants contained in hospital effluents on Daphnia magna. Ecotoxicology 16:327-340.

https://doi.org/10.1007/s10646-007-0136-2

43. Pati SG, Arnold WA (2020) Comprehensive screening of quaternary ammonium surfactants and ionic liquids in wastewater effluents and lake sediments. Environ Sci Process Impacts 22:430-441. https://doi.org/10.1039/C9EM00554D

44. Penteado JCP, El Seoud OA, Carvalho LRF (2006) Alquilbenzeno sulfonato linear: uma abordagem ambiental e analítica. Quím Nova 29:1038-1046. https://doi.org/10.1590/S0100-40422006000500025

45. Pereira BMP, Tagkopoulos I (2019) Benzalkonium Chlorides: Uses, Regulatory Status, and Microbial Resistance. Appl Environ Microbiol 85:e00377-e00319. https://doi.org/10.1128/AEM.00377-19

46. Perrodin Y, Bazin C, Orias F et al (2016) A posteriori assessment of ecotoxicological risks linked to building a hospital. Chemosphere 144:440-445. https://doi.org/10.1016/j.chemosphere.2015.08.075

47. Perrodin Y, Christine B, Sylvie B et al (2013) A priori assessment of ecotoxicological risks linked to building a hospital. Chemosphere 90:1037-1046. https://doi.org/10.1016/j.chemosphere.2012.08.049

48. R Core Team (2020) A Language and Environment for Statistical Computing. R Foundation for Statistical Computing, Vienna 
49. Roberts DW (2003) Optimisation of the Linear Alkyl Benzene Sulfonation Process for Surfactant Manufacture. Org Process Res Dev 7:172-184. https://doi.org/10.1021/op020088w

50. Ruan T, Song S, Wang T et al (2014) Identification and Composition of Emerging Quaternary Ammonium Compounds in Municipal Sewage Sludge in China. Environ Sci Technol 48:4289-4297. https://doi.org/10.1021/es4050314

51. Santa Bárbara MC, Luriko Miyamaru L, Miyoco Yano H et al (2012) Qualidade de saneantes e antissépticos utilizados em hospitais da rede pública. Rev Inst Adolfo Lutz Impresso 71:650-655

52. Souza FS, Silva VVD, Rosin CK et al (2018) Determination of pharmaceutical compounds in hospital wastewater and their elimination by advanced oxidation processes. J Environ Sci Health Part A 53:213-221. https://doi.org/10.1080/10934529.2017.1387013

53. Steber J (2007) The ecotoxicity of cleaning product ingredients. In: Handbook for cleaning/decontamination of surfaces, 1 st edn. Elsevier Science, Amsterdam, p 992

54. Sultana H, Bokhari TH, Usman M (2021) Adsorptive micellar flocculation (surfactant-based phase separation technique): Theory and applications. J Mol Liq 323:115001. https://doi.org/10.1016/j.molliq.2020.115001

55. Tadros TF (2013) Emulsion Formation, Stability, and Rheology. In: Emulsion Formation and Stability. John Wiley \& Sons, Ltd, pp 1-75

56. Top S, Akgün M, Kıpçak E, Bilgili MS (2020) Treatment of hospital wastewater by supercritical water oxidation process. Water Res 185:116279. https://doi.org/10.1016/j.watres.2020.116279

57. Verlicchi P, Galletti A, Petrovic M, Barceló D (2010) Hospital effluents as a source of emerging pollutants: An overview of micropollutants and sustainable treatment options. J Hydrol 389:416-428.

https://doi.org/10.1016/j.jhydrol.2010.06.005

58. Von Sperling M (2014) Introdução à qualidade das águas e ao tratamento de esgotos, 4th edn. Editora UFMG, Belo Horizonte

59. Wang Y, Zhang Y, Li X et al (2015) Exploring the Effects of Different Types of Surfactants on Zebrafish Embryos and Larvae. Sci Rep 5:10107. https://doi.org/10.1038/srep10107

60. Wiest L, Chonova T, Bergé A et al (2018) Two-year survey of specific hospital wastewater treatment and its impact on pharmaceutical discharges. Environ Sci Pollut Res 25:9207-9218. https://doi.org/10.1007/s11356017-9662-5

61. Ying G-G (2006) Fate, behavior and effects of surfactants and their degradation products in the environment. Environ Int 32:417-431. https://doi.org/10.1016/j.envint.2005.07.004

62. Zhang C, Cui F, Zeng G et al (2015) Quaternary ammonium compounds (QACs): A review on occurrence, fate and toxicity in the environment. Sci Total Environ 518-519:352-362.

https://doi.org/10.1016/j.scitotenv.2015.03.007

63. Zion Market Research (2021) Antiseptics and Disinfectants Market By Type (Alcohol and Aldehyde and Phenols and Derivatives, Biguanides and Amides. In: Quaternary Ammonium Compounds, lodine Compounds, and Others) By End User (Domestic and Institutional): Global Industry Perspective, Comprehensive Analysis and Forecast, 2020-2028. Zion Market Research, New York

64. Zotesso JP, Cossich ES, Janeiro V, Tavares CRG (2017) Treatment of hospital laundry wastewater by UV/H2O2 process. Environ Sci Pollut Res 24:6278-6287. https://doi.org/10.1007/s11356-016-6860-5 